\title{
Application of Concept Maps and Critical Thinking Ability to Improve Writing Reports
}

\author{
Martono $^{1),}$ Susanti $^{2),}$ Suprapti ${ }^{3)}$ \\ ${ }^{1)}$ Tanjungpura University \\ E-mail: martono_fkipuntan@yahoo.co.id
}

\begin{abstract}
This study was conducted in class VIII C SMP 21 Pontianak City in 2015/2016. The study focused on the material report. Materi subject matter for the report is required to master this material student. Students so that they can write a trip report or reports on the observed results. they report should refer to the nature report. The fact write in school, students have difficulty writing reports. efforts to improve the ability of students to write a report done by the application of concepts and critical thinking questions. The focus of this research is how the application of the concept maps and critical thinking in improving report writing capability class VIII C SMP 21 years of 2015/2016? The scope of the research is focused on a few sub focus namely research, planning, implementation, and the result. The research method is descriptive and qualitative research design form of class action. Results of research learning planning cycle 1 (APKG1) values obtained 85.00 (very good), 2 cycles values obtained 97.50 (very good). Learning implementation using APKG2, the activities of teachers in the first cycle, the first and second meetings have been categorized Very Good, with a value of 87.20. Activities teachers teach when the second cycle, the first meeting and the second is better, with a value of 88.80 . If the student activity cycled see first, first and second meetings are very active and are included active. Good Cycle. This second, first and second meeting, there was an increase in the student activity is said to be better than the first. Every cycle and every member of the group to work independently and be careful in teaching. cycle values of individual students: the average is 79.39. There is a group formed in learning activities. The final average group value 84.00 . Second cycle. Values of individual students from three aspects, the average is 79.39 . value incomplete $26.8 \%$. group value Rate Average 88.00 . 87.56 absorptive capacity. There was an increase in the average value of cycle 1 to cycle 2 , at 4 . But the value of the individual is constant.
\end{abstract}

Keywords: report, concept maps, critical thinking.

\section{INTRODUCTION}

Materials report is subject matter to students are required to master the material VIII. A student in the class is so they can write a trip report or report they wrote observed. The report should refer to the nature of the report. This material will be very useful to them if continue to pursue education. Teachers/professors often give assignments to the students/students to observe something or make a report on the work. The task was given by teachers/lecturers they should do.

The reality of the school, students have difficulty writing a trip report. Based on discussions with teachers-researchers, students have difficulties when writing a trip report or report observations. Difficulties such students cannot identify what will be reported, the order of presentation of the reporting, the ability to develop his idea.
This research was conducted at SMPN 21 because this school including the data integrated. Berdasarkan school students who enter at this school come from primary schools around the school. The school that around has different. If school accreditation visits from elementary school would have a lot of criteria.Tentu competence of students is very diverse.

The research was done in class VIII $\mathrm{C}$ because in this class students who completed the learning little writing trip reports/observations. Students who complete only $30 \%$ of 41 . This perceived by teachers as students in this class have a low academic ability, therefore, the research done in class VIII C.

Based on these discussions, I find a solution to overcome the problems experienced petrified teacher. the method of map concepts and critical thinking as a solution to overcome the problems experienced by teachers in school. Peta concept by Martin (in Trianto, 2009 ) is an important new innovation to help children 
produce meaningful learning in class. Peta concept of providing a visual aid concrete to help organize the information before the information is learned.

Concept maps help teachers understand the various concepts embedded in the materials to learn for the larger student. Understanding the concept maps would improve teacher made learning plan. Clear mapping can help avoid misconceptions formed student. Concept map-making is done by creating a visual presentation or a diagram of how important ideas or a specific topic linked to one another.

By compiling a map of concepts and critical thinking students are expected to be drafted in order logic. Sequentially ability drafting the necessary thought critically. Based Perkin (in Eggen and Don, 2012) study is the impact of thinking. Retention, understanding, and active use of knowledge can be created only with the learning experience of students to think about and think about what they learned.

Report writing material had Competency Standards Writing 4. Disclose information in the form of reports, official letters, direction. Basic Competency 4.1. Write a report with good language and right. Indicator: 1. Able to draw up a report template in order of space, time, or theme, 2. Able to develop reporting templates with communicative language.

\section{METHODS}

This descriptive most effective method used in this study because researchers wanted to get a true picture of the implementation of the map concept and critical thinking in improving report writing capability class VIII C SMP 21 years 2015/2016.

The shape of this study design is qualitative. Researcher chooses qualitative terms as deemed appropriate by the issues to be investigated which describe the planning process, and learning to write a report based on the application of the concept maps and critical thinking.

Data Sources and Data Research

a. The data source in the study of this class action is.

1. Teachers in this study is a teacher at SMPN 21 Pontianak Ms Susanti, M.Pd. which act as implementers of learning. Me and Mrs Suprapti, M.Pd. SMPN 8 Pontianak as an observer course of teaching and learning. Dani helped take pictures.

2. Students were students VIIIC class numbered 41 people. Students are required to obtain data about the activity and student learning outcomes by applying in writing reports and critical thinking concept maps.

3. RPP made by teachers and researchers about learning to make a report.

b. Research Data

The data in this study include planning, implementation, and student learning outcomes by applying in writing reports and critical thinking concept maps.

Techniques and Tools Data

a. Collectors. Data Collection Techniques

Data collection techniques used by researchers is as follows.

1) Observations

Researcher and Mrs Suprapti, M.Pd. act as observers to observe directly the activities of teachers and students during the learning takes place.

2) The data collection techniques with Docs

Researchers analyzed the documents to obtain data on the learning plan (RPP) in writing reports by applying the concept maps and critical thinking.

3) Measurement

The researcher is used to collect information on the knowledge, attitude, talent and more about the activities of writing a report on a variety of research procedures to determine the learning outcomes of students in writing reports.

b.Data Collectors Tools

1) Observation Sheet

Researcher uses observation sheets (APKG 2) to assess the implementation process of learning. In this study, the assessment carried out by research in the learning implementation and Mrs Suprapti, M.Pd.

2) Documents

Researchers used APKG 1 to assess the RPP which has made. Researchers also used the documents the work of students in learning to write reports using concept maps and critical thinking.

3) Essay

Essay tests used by teachers to determine the student's ability correctly frame the report and to develop a concept map it into a logical statement, good, and true.

\section{Data Analysis Techniques}

Sugiono(in Iskandar, 2013: 74) qualitative data analysis is the process of systematically searching for and compiling data obtained from observations and make conclusions so easily understood by myself and others. The data analysis technique is how that is done in analyzing the data. Data analysis technique is a way that the writer used to analyze the data. The measures that will be used in the data analysis in this study as follows.

a. Analyzing the learning plan (APKG 1) write a trip report to apply the concept maps and critical thinking.

b. Analyzing the implementation of learning 
(APKG 2) write a trip report to apply the concept maps and critical thinking.

c. Analyzing the results of students

in writing a trip report to apply the concept maps and critical thinking.

d. Conclusion.

\section{RESULTS}

\section{A. First Cycle}

1. Learning Implementation Planning Concept maps and Critical Thinking in Writing Report

Research is conducted as originated from discussions between researchers with Mother Susanti, M.Pd. Discussion by telephone and believed that Ms Susanti WA. Researcher has a good competence. Discussion on the Indonesian language learning in schools. Students are still having trouble writing report. Based discussion, then I try to find solutions to help overcome the problems faced by Ms Susanti, M.Pd. I examine theories that can be used to enhance the student's ability to write reports. I decided to apply the critical thinking concept maps and

Discussions continued after it was decided to apply the concept map and think critically. Researcher and Ms Susanti, M.Pd. RPP compiled the material to write a report to apply the concepts and thinking maps were drawn critically. RPP discussed various aspects in order to become better. After that, finished preparing lesson plans, agreed to apply the concept map and think critically. The study was conducted on August 11, 2016, cycle 1, the first meeting.

Implementation of the first cycle of learning, the first meeting starts at 10: 50-12: 10. I had arrived at the school at about 10: 00 . Before going to class, we discuss the material to be conveyed and the steps that must be performed by Ms Santi. After discussing and learning time started, we headed to the second class. The learning held on Friday, August 12th, 2016.Penilaian lesson plan to do after the first and second meetings.

\section{Learning Implementation Cycle Observation 1} First Meeting and the Second Application Map of Concept and Critical Thinking in Writing Reports

presented next step is to report the results of observation for teaching and learning take place. The observations focused on the lesson plan, the implementation of learning which includes activities teachers teach and students' activity during the process of learning takes place and learning outcomes. RPP used by teachers when teaching and learning very important. Therefore, the current focus of research was done. RPP the reference teacher while teaching at class. Researcher use format APKG 1 to assess the RPP.

Teachers in the teaching and learning activities is a critical success factor in learning in the classroom. Teachers who design, implement, and assess the work of students in the classroom. Teachers should be able to apply the learning steps that have been created. Observation of the activity of teachers in this study is very important. To view the activity of teachers based on the correspondence between planned in the RPP in fact implemented in the classroom. Was there a difference, or the same as those contained in the RPP? If there is a difference why it happened? To view the activity of teachers teaching researchers used observations format APKG 2.

In this study, the student's activity during learning become the focus researcher. Activity students are important in learning activities. The student should feel happy and enjoy during learning activities. Their teaching should not be afraid and scared. Teachers ability to enable students in learning activities is crucial.For see the activity of students in learning activities using the format student. Activity results an in this area is less focused. Good value and excellent not studied this section.

a. Planning Observation Learning

Activities the first cycle, the first meeting and the second study, researchers looked at the plan for learning activities that teachers do teach teaching and learning. Tailored activity to the learning plan. Researchers will look at whether there is a difference or not. Based on the results of the assessment conducted based on the APKG 1, it can be described as follows.

RPP made teachers and researchers after learning activities they found lacking. A score of 3 (or less) in section C (development of materials and teaching materials), namely the number 4, (the learning materials were translated into adequate teaching materials and in accordance with the theory). The materials delivered yet to be made in the form of teaching materials. Teachers only take the material in the book. This is understandable because of the limited time for teachers to prepare teaching material independently.

Value 3 (less) contained in section D (the selection method of learning), the number 2 (the learning method supports the activities of PBI listed is truly reflected in measures of learning. The first meeting of this, there is still a step teaching-learning 
which is still not good. Less sequence and timing. this occurs because of less time spent. Therefore, teachers need extra help students create/prepare a concept map.

a score of 3 (or less) contained in section $\mathrm{E}$ (preparation of the lesson), the number 2 (core activities), a. (core learning gives students the opportunity presents results of individual work based discussion groups). The teacher does not allow students present the results of their work is written on the board. This has happened for the first meeting of the allocation of time is not maximized.

b. Observation activities Master in Cycle 1

In the first cycle, the first and second meetings of teachers present material to write a report on 11 and 12 August, 2016. The presenting this material and the principal investigator undertake observed. Based observations they found valuable aspects 3 (less) valuable. Aspect 3 (less) is the beginning of a number of activities (5) provides motivation. Why rated 3? Having studied, teachers lack the motivation to write a report. The relating to the material described benefits students when they learn to write reports using concept maps and critical thinking.

Aspects worth three (or less) is the aspect of approach/learning strategies, number 3, namely: implementing learning with concept maps out strategy and critical thinking. Why rated 3 (less)? Activity Core contained in the RPP after learning activities was found to be fixed. Disorderly activities sequence of learning activities that lead to the poor realization of students in learning activities. Exploration activities to be carried out are as follows:

a. The teacher divides the students into groups, each group consisting of 4-5 students,

b. Students observe the text of the report submitted by the LCD teachers,

c. Students and teachers to discuss the preparation of the correct concept map,

d. Students discover how to prepare a map the correct concept

e. Students discuss construct concept maps based on the text of the report,

f. Students observe the environment SMPN 21 Pontianak (NK: austerity)

g. Students discuss preparing concept maps to observe the activities of SMPN 21 Pontianak,

h. Students prepare report observations.
Section teacher activity, the teacher activity found its focus is still uneven. This is due to the activity of students in learning activities that are very good, as a result of teachers experiencing "confusion" to designate a group expression or working group. The focus of the teacher to the student section or the left or right side when facing student. This teacher occurs because the group was quickly raised when asked to answer questions from the teacher. Looked " confusion " teachers still give praise to the group who can answer questions or provide feedback to the teacher.

c. Observation of student activity

Current activity student learning activities seem very active. Student very seriously listening to the explanation of teachers currently teaching. When the teacher gives students the opportunity to ask questions, many students ask questions related to the teacher's explanation. Students are not afraid and are embarrassed to ask because they do not understand. There are groups who have difficulty making concept maps. Teachers are very responsive and provide guidance to groups who do not understand the concept map.

Students are asked to draw up a concept map. After drawing up a concept map, students observe the school environment. Then the students discuss the results of the observation report. Each group member drafts and puts them together in a collected report. Once completed, the group leader is prepared to submit his group work report.

Each group reported the results of group work. The other group responds to reports of other groups. There are groups that add to the reports of other groups. During this teaching-learning activity, the teacher gives a gift to a good group. Group 10 finished report (first order), group 9 finished report (second order), group 3 finished report (third order). There are groups that respond. A group is a group of 7 . Group 7 gave a report and add or provide fill to the group 10, and group 9. Each group worked very seriously and take The answer. Thus teamwork evident when they make observations and then make concept maps and reports. Active students in learning teacher. When relies heavily on teacher learning activities always go to each group. 
2. Reflections on Learning Implementation and Application of Critical Thinking Concept Map

Based on the results of learning activities, observation and assessment, then the discussion after learning activities take place. Based on the observed data, then the talks related findings.

a. Lesson planning

lesson plans are developed and implemented in learning activities discovered steps that still must recover. These steps were difficult for the student. Therefore, must be improved lesson plans that made. The goal this improvement is that in learning activities into a coherent teaching and help students understand the material presented teachers.

b. Teacher activity

Masters a mediator in learning activities. Teachers have good conduct activities learning. But employ no activities that teachers in learning activities should be improved to be more highly. It was realized by the teacher. For example, an active situation makes teachers' confusion "refers to the group to deliver their report. The second cycle teachers conditions hope to remain active, calm, and always look at each group.

c. Activities of students

Students are children who are learning. The teacher act that makes children actively learn and understand the material presented by the teacher. The teaching and learning activities, students actively in learning. Activity, as evidenced by the completion of their students, create concept maps and critical thinking in writing reports. Conditions are very active in the classroom communicative. Each group work together in completing the task of the teacher. After doing their duty is also active (competing) to report the group's work.

\section{Student Learning Outcomes}

Assessment This study is based on two criteria, namely individual assessment, and appraisal group. The assessment individually made to see the capacity of each student. Component assessed construct concept maps (score 5), stringing concept maps into a report ( a score of 10), and the accuracy of the use of spelling and punctuation (score 5). Classical learning completeness of $77.5 \%$. There are still $26.8 \%$ incomplete.

a. Individual Students value is

an average value of individual students in preparing a concept map 87.32. 5 highest value and lowest value 1.There 29 students who received grades 5 . There were 11 students who received grades 3.Berdasarkan data recap students value the average value has been good.But still found students who do not understand the concept maps compiled, the students were the initials MA. student scored 1. students must be considered when learning.
Looked Annex nilasi 1. Cycle students in the second cycle, students individually can better prepare concept maps and the average classical higher.

The average value of students stringing concept maps into reports 76.34. The highest value 10 . Ada 12 students who received grades 10.Ada 24 students who received a score of 7 . There were 5 students who obtained a value of 5. This component has been categorized as good as the average value of class 76,34 . It is expected that in the cycle second, many students (80.00) which can apply the concept maps into reports. The second cycle is expected to average higher class.

The average value of students in applying spelling and punctuation 77.56. 5 highest value and the lowest value of 3 . There are 18 students Yeng obtain a value of 5 . There were 23 students who received grades recap 3. Based on this average value of student understanding in applying spelling and punctuation good category, 77.56. It is expected that at the meeting of the second cycle, students can apply spelling and punctuation better and the average value of its class to be increased.

b. Group Students value in

Aspects assessment group include preparing concept maps, concept maps assemble into reports, correct use of spelling and punctuation. Weight construct concept maps highest and lowest 50 , weight stringing concept maps into reports at most 10, most low 5. Thickness accuracy spelling and punctuation use at most 10 , the lowest 0 . The group prepares high concept maps least 5 (there are 8 groups), the lowest score of 3 (2 groups). The average value of 92, 00 and absorbency 86.67. Based on the average value and absorbency prove student. This showed the students have the ability to understand and apply maps and concept maps concept. Apply critical thinking ability is very useful for students as they live in the community or if they continue their studies.

Value stringing concept maps became the highest report 10 (there are 6 groups) and the lowest value obtained 7 (4 groups). Mean values were 88.00 and 91.11 absorption. Based on the results of the group then the student has the ability to assemble into the report. Stringing concept map ability concept map into a report requires competence or skills of the students. If the students have skills honed and directed, it will produce a quality report.

Value correct use of punctuation spelling and at most 10 (2 groups), and the lowest 
value obtained 7 (there are 8 groups). The average value of the accuracy of the use of spelling and punctuation and absorbency 77.78 76.00. Based on the results of the assessment of students categorized recap understand and can implement the use of spelling and sign reading competences. If spelling and punctuation usage of the students can be developed, it would be a good student writing.

There are ten groups that participated in the study learning. Students activity in the group to the attention of teachers and collaborator. After assessment and recapitulation, then there are nine groups completed and only one group declared incomplete namely the 8 .

\section{B. Second Cycle}

Implementation of the second cycle is done after The first cycle stages implemented. The focus of the study was revised based on the results of assessments based on the APKG 1 to assess teachers' planning time and APKG 2 conducted to assess the implementation of learning that teachers do.

\section{Lesson Planning Application Map of Concept and Critical Thinking in Writing reports}

Teaching and learning activities of the second cycle the first meeting held on 1 September 2016 and the second meeting held on 2 September 2016.Kegiatan learning first and second meeting use lesson plans are revised according to the results of meeting the first cycle and secondly, especially the results reflected. Some record results in the first cycle of the first and second meeting became the basis for a revised plan that has been revised teaching-learning. The plan is a guide when teachers teach in class. After revised and lesson plans used for the teaching and learning activities can be seen in the attachment. Based on observation of lesson plans, good category. Good and very well against the aspects considered.

\section{Learning Implementation Cycle 2 Application Map of Concept and Critical Thinking in Writing Report \\ of the second cycle of the first meeting held on} September 1, 2016. The implementation of the learning cycle 2 , the first meeting starts at 10: 5012: 10 . Before getting into the class, we discuss the material to be conveyed and the steps that must be performed by Ms. Santi. The lesson plan has been revised based on the findings First cycled. After discussing and learning time started, we headed to class.

The learning activities are the second meeting held on Friday, September 2 2016.Penilaian lesson plan to do after the first meeting and Second learning. The implementation was done by RPP below.

\section{Learning Implementation Cycle Observation 2 Meeting of the First and Second Application Map of Concept and Critical Thinking in Writing Reports}

At this stage, especially observing the results of the implementation of learning a second cycle of the first meeting and the Second meeting. This section, the next step is to report the observations presented during learning activities teaching takes place. The observations focused on the lesson plan, the implementation of learning which includes activities teachers teach and students' activity during the process of learning takes place and learning outcomes. Learning Plan at a meeting of the second cycle is already revised. The revised done because there are weaknesses in the first meeting and the Second meeting RPP. RPP used by teachers when teaching and learning very important. Therefore, the current focus of research was implementation. RPP the reference current teachers teaching in the classroom. Researchers used format for assessing APKG 1 RPP.

The second cycle of the first and second meetings remain the focus of attention of collaborators to see activity teaching-learning. Teachers in learning activities is a critical success factor in learning in the classroom. Teachers who design, implement, and assess the work of students in the classroom. Teachers should be able to apply the learning steps that have been created. Observation of the activity of teachers in this study is very important. To view the activity of teachers based on the correspondence between planned in the RPP in fact implemented in the classroom. Collaborators using observation guidelines, APKG 2 which contains the components teacher teaches.

The second cycle of the first and second meetings remain the focus of attention of collaborators to see the activities of students attend learning activities. This research, student activities during learning become the focus of researchers. Student activity is important in learning activities. The student should feel happy and enjoy during learning activities. They should not be afraid and be down. Teachers ability to enable students in learning activities is crucial. For see the activity of students in learning activities using activity format student. The results in this section is less focused. Good value and very well not be reviewed in this section.
a. Planning Observation Learning
Event a second cycle, the first meeting and the second study, researchers looked at the plan for learning activities that teachers do teaching- 
learning. Tailored activity to the learning plan. Researchers will look at whether there is a difference or not. Based on the results of the assessment conducted based on the APKG 1, it can be described as follows.

RPP made teachers and researchers after an already good teaching and learning activities. Not found value (3) which less. The score is given by collaborators as an observer with the value (4) good, and value (5) is good. This proved learning plan revised/improved based on the results of the first cycled reflection, the first and second meetings, For value (5) is either not translated into more details. To analysis can be seen in this attachment. In this part described value (4) either.

Value (4) either be given a collaborator on aspects: C (develop materials and teaching materials) number 4 (the learning materials were translated into adequate teaching materials and in accordance with the theory. Aspects of D (the selection method of learning) the number 3 (the learning method in accordance with the characteristics students. Aspects of E, No. 2 (core activities) section $\mathrm{d}$ (core learning provides the opportunity for students to think, analyze, collaborate with friends or interact with teachers.

b. Observation Activities Master in cycle 2

in the second cycle, the first meeting and two teachers present the material of writing the report on September 1 and 2 in 2016. Currently presenting this material researchers and collaborators make observations. Based on observations found no value 3 (less). This happens because the activity discussed teachers who are still not good at the time of reflection.Therefore, the next meeting on the second cycle is good.

Values (4) can be seen in aspects I (Preliminary Activity), number 1. Checking student readiness, number 4. Explaining the benefits of understanding the observation report, and number (5) providing motivation.Value (4) also section II. Core Activities, Aspects (Core Activities), Part A. Mastery of instructional materials, number 2. Associate report writing materials with other relevant knowledge or with other relevant knowledge. Value (4) is also Part B. Approach/learning strategy, number 3 . Implement learning with the strategy of concept map application and critical thinking. Number 5.Motivating less active students in discussion, number 6. Implementing learning according to time allocation. Part C, Learning that triggers and nurtures student involvement, number 2 . Grows an open attitude toward student responses. Part D. Assessment of learning process and outcomes, number 2. Conduct active assessment in accordance with learning objectives. Part E. Use of language. Number 2. Deliver messages inappropriate language levels of students.

c. Observation of student activity

Teaching and learning activities in the second cycle, the first and second meetings are very active. This activity occurs because the teacher can master the class. The teacher's support while teaching students enjoy in learning. Student activity during teaching and learning activity seems very active. Students are very serious to listen to teacher explanation during teaching and learning activities. When teachers give the opportunity to students to ask, many students ask questions related to teacher explanation. Students are not afraid and shy to ask because they do not understand.

Students are asked to create concept maps. There are groups who have difficulty making concept maps. Teachers are very responsive and provide guidance to groups who do not understand the concept map. After creating a concept map, students observe the school environment. Then the students discuss the results of the observation report. Each member of the group drafts and puts them together in a collected report. Once completed, the group leader is prepared to submit the group's work report. Each group reports group work. The other group responds to reports of other groups. Many groups give additional reports to other groups. This proves the accuracy of each member of the self-reliant group and critical thinking while performing the tasks assigned by the teacher.

\section{Reflection on the Implementation of Implementation Implementation of Concept Map and Critical Thinking}

Based on the results of learning activities, observation, and assessment, then the discussion after teaching and learning activities took place. Based on the observation data, then the talks related findings.

\section{a. Lesson planning}

Planning implemented in teaching and learning activities in the second cycle, the first meeting, and the second is the result of the discussion reflected the first cycle. Learning planning that is developed and applied in teaching and learning activities is good. The revised learning steps have been very good. These steps felt made enjoy students in learning.Therefore, the 
second cycle of teaching-learning activities, the first meeting and the second run well.

b. Teacher activity

In teaching and learning activities in the second cycle, the first meeting and the second meeting of teachers remain a mediator. Teachers have good teaching and learning activities. This happens because the teacher has excellent competence in mastering the class and mastering the learning materials. Activities that teachers do in teaching and learning activities should be maintained more very well.

c. Student activity

In the second cycle of teaching and learning activities, the first meeting and second meeting of activities are good. Student activity is evident with the completion of them making concept maps and critical thinking in writing reports. When students are asked to observe around the school and give time to the teacher, the students make the best use of the time. After making the student observations back into the classroom. Conditions in the classroom are very active communicative. Each group works together in completing the task of the teacher. After doing the task they are also active (competing) to report the results of group work. This proves the accuracy and independence of each member of the group while doing the tasks assigned by the teacher.

\section{Student Learning Outcomes}

This assessment of learning is done based on two criteria, namely individual assessment and group assessment. Individual assessment is done to see the ability of each student. The assessed components are drawing up concept maps (score 5), compiling concept maps into reports (score $10)$, and accuracy of spelling and punctuation (score 5). The learning completeness classically in the second cycle is $90.24 \%$. There is still an incomplete $9.75 \%$.

a. Student's Values Individually

The average value of students individually in preparing the concept map 100.Value 5. There are 41 students who scored 5. Based on the recap of student value data, the average value of this is good. The student has been able to understand the nature of concept maps and can arrange concept maps. The average score of the students is drafting the concept map into a report of 80.73. The highest score 10 . There are 18 students who scored 10. There were 18 students who scored 7. There were 5 students who scored 5. This component is already in the good category because the average grade is 80,73 .
Average grade of students in applying spelling and punctuation 79,51. The highest score 5 and the lowest value 3 . There are 20 students who get the score 5 . There are 21 students who scored 3 . Based on the recap average value is students' understanding of applying spelling and punctuation including good category, 79.51. It is hoped that in the second cycle meeting, students can apply better spelling and punctuation and the grade point average increases.

Based on the three aspects assessed and combined value, the final value is an average of 85.24. The Classical order is 90.24. There are still students who are not complete namely: 9.75. (there are students: $\mathrm{AP}, \mathrm{AD}$, $\mathrm{SF}$, and YDN). Their final grade is 65 .

b. Student Values Group

Aspects of group appraisal include drawing up concept maps, drafting concept maps into reports, precise use of spelling and punctuation. The weights compose the concept maps as high as 5 and the lowest 0 . The weighing up the concept map becomes the highest report 10 , the lowest 5 . The weight of the spelling and punctuation accuracy is 10 , the lowest is 0 .

The group values make up the concept map as high as 5 (there are 10 groups). Its average rating is 100 and its absorption is 91.11. It shows students have the ability to understand and apply concept maps.

The value of concocting the concept map becomes the highest report of 10 (there are 8 groups) and the value obtained is the lowest of 7 (there are 2 groups). The average score is 94.00 and the absorption is 95.56 . Based on the result of group value, the students have the ability to assemble concept maps into reports.

The value of spelling and punctuation accuracy is highest 10 (there are 2 groups), and the value obtained is lowest 7 (there are 8 groups). The average value of accuracy of spelling and punctuation is 76.00 and its absorption is 77.78. Based on the recap of the results of the assessment students are categorized understand and can apply the use of spelling and punctuation.

The final value is based on the merging of three aspects, which compose concept maps, concatenate concept maps into reports, spelling accuracy and punctuation are 88.00 average, absorbency 87.56. Classical mastery 100 .Value 100 there are 2 groups. The value of 88 there are 6 groups, the value of 76 there are 2 groups. 


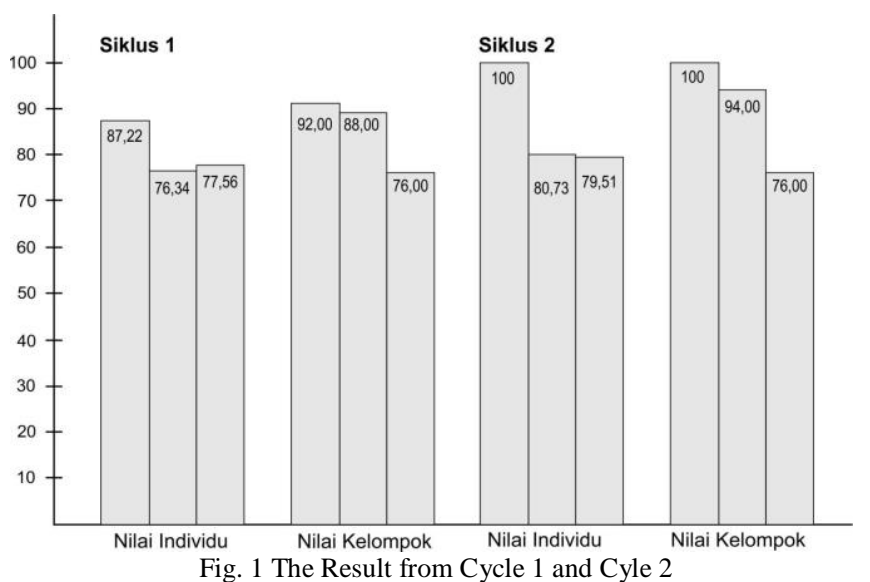

Individual Value:

1. Develop concept maps

2. Construct concept maps into reports

3. Apply spelling and punctuation

Group Value:

1. Develop concept maps

2. Construct concept maps

3. Accurate use of spelling and punctuation

\section{IV.CONCLUSION}

\section{A. Conclusion}

1. Planning learning first cycle, first and second meeting, there are still shortcomings. After the second cycle of learning, the second meeting held a reflection. Changes made to improve teaching and learning process to be active and "enjoy" (fun). Based on the assessment results using APKG 1 first cycle of the first meeting and the second meeting, then obtained value 85.00 (very good). The value of the second cycle planning, the first meeting and the second meeting, then the results obtained based on APKG 1 is 97.50 (very good). There is an increase in the results of first cycle planning and the second cycle 12.5 .

2. Implementation of learning done as much as two cycles. Focus attention on teacher activity and student activity. Based on the results of the assessment using APKG 2, the teacher activity in the first cycle, the first meeting and the second has been included in the category of Very Good, with a value of 87.20. Teacher activity teaching during the second cycle, first and second meeting is better, with value 88,80 . If you see first-cycle student activity, the first and second meetings are very active and good. This is already active. The second cycle, the first and second meeting, the student activity there is an increase can be said to be better than the first cycle. Tianeach member of the group works independently and meticulously in the work of the teacher. After each member performs the task then put together into a group report.

3. Based on the results of the first cycle and the second cycle, it can be described as follows. The first cycle.
Students' individual values make up an average concept map of $87.32 \%$. The absorption rate of $89.32 \%$. The value of drafting the concept map becomes the average report: 76, 34. Its absorption is 76.34. Spell correctness and punctuation value 77.56. Its absorbency is 77.56. The final value of the three aspects then, the average is 79.39. Absorption 79.39. 77.5\% complete classical. An unfinished score of $26.8 \%$. Group value. There are ten groups formed in teaching and learning activities. Arranging the concept map of his rare 92.00, absorption 86.67. The value of drafting the concept map becomes the average report of 88.00. Absorption 91.11. Spelling accuracy and punctuation average value are 76.00. Absorption power of 77.78. The final grade of the group. Average 84.00. The second cycle. The student's individual score constructs the average concept map $100 \%$. Absorption 100\%. The value of drafting concept maps becomes the average report: 80.73 . Its absorption is 80.73. Spell correctness and punctuation value 79.51. Its absorbency is 77.56. The final value of the three aspects then, the average is 79.39. Absorption 79.39. 77.5\% complete classical. An unfinished score of $26.8 \%$. Group value. There are ten groups formed in teaching and learning activities. Arranging the concept map with 100.00 absorption ratio 91.11. The value of drafting the concept map becomes an average report of 94.00. Absorption 95.56. Spelling accuracy and punctuation average score of 76.00. Absorption power of 77.78. The final score of the group. Average 88.00. Absorption 87.56. There is an increase in the average value from cycle 1 to cycle 2 , amounting to 4 .

\section{B. Suggestions}

Based on the results of research, it can be given some suggestions.

1. Teachers as facilitators in the process of teaching and learning activities. Therefore, teachers must be creative in preparing lesson plans. Learning planning is the key to a teacher's success. In the planning of learning, there are components of objectives, materials, media, methods, learning strategies, evaluation. Teachers should be able to choose innovative teaching methods, learning strategies, evaluate them appropriately.

2. Concept maps and critical thinking have been proven to improve students' writing skills. Teachers can use concept maps and critical thinking when delivering report writing materials. In addition to improving the ability to write reports, teaching and learning conditions become more enjoyable for students. There is an active communication between students and students, students with teachers.

3. The principal must support teachers who do creativity in teaching. A form of assistance by equipping the facilities in the school. If the facilities and infrastructure in schools are good and complete will certainly motivate teachers to be innovative in teaching. 


\section{REFERENCES}

Arikunto, Suharsimi, (2008). Prosedur Penelitian suatu Pendekatan Praktik. Jakarta: Bina Aksara.

Egan, Kieran. (2009). Pengajaran yang imajinatif. Jakarta: PT INDEKS.

Eggen dan Don. (2012).Strategi dan Model Pembelajaran Mengajar Konten dan Keterampilan Berpikir. Penerjemah: Satrio Wahono. Jakarta: PT Indeks

Harmin, Merrill dan Melanie Toth, (2012). Pembelajaran Aktif yang Menginspirasi.Buku Pegangan Lengkap untuk Guru Masa Kini. Penerjemah: Bethari Anissa Ismayasari. Jakarta: PT Indeks.
Iskandar. (2013). Penelitian Tindakan Kelas. Ciputat: Gaung Persada Press.

Trianto, (2007). Model-Model Pembelajaran Inovatif Berorientasi Kontruktivistik.Konsep, landasan Teoritis-Praktis dan Implementasinya. Jakarta: pprsby@plasa.com

Trianto. (2009).Mendesain Model Pembelajaran Inovatif Progresif. Konsep, Landasan, dan Implementasinya pada Kurikulum Tingkat Satuan Pendidikan (KTSP). Jakarta: Kencana.

Wirjaya, Asep Yuda. (2010). Berbahasa dan Bersastra Indonesia. Jakarta, Depdiknas. 